\title{
Karyotypic and Morphometric Studies in Two Species of Family Planorbidae (Gastropoda: Mollusca)
}

\author{
Poonam $^{1 *}$, N.K. Tripathi ${ }^{1}$ and Preetpal Kour ${ }^{2}$ \\ ${ }^{1}$ Department of Zoology, Central University of Jammu, Rahya-Suchani (Bagla), District \\ Samba-181143, Jammu, India \\ ${ }^{2}$ Department of Zoology, GCW Parade, Jammu, India \\ *Corresponding author
}

\section{A B S T R A C T}

\section{Keywords \\ Planorbidae, \\ Chromosome, Meiosis \\ Article Info \\ Accepted: \\ 08 August 2018 \\ Available Online: \\ 10 September 2018}

During the present study, mitotic chromosomes of two freshwater snails Gyraulus ladacensis and Indoplanorbis exustus were analyzed using ovotestis of specimens collected from the type locality (Nud pond Samba, Jammu), both belonging to class Gastropoda, order Basommatophora and family Planorbidae. The observed diploid chromosome number was $2 n=36$ consisting of 14 metacentric pairs, 03 submetacentric pairs and 01 subtelocentric pairs and 18 pairs of metacentric pairs respectively. Meiotic observations comprised leptotene, zygotene, pachytene, diplotene and diakinesis stages. Results of the present study have scientific and practical significance complementary to biochemical and molecular studies in animal taxonomy.

\section{Introduction}

Phylum Mollusca constitutes one of the major divisions of the animal kingdom and are of unusual interest both in regard to the diversity of organization and in the multitude of living species. Molluscs represent one of the most diverse and species-rich phyla of the animal kingdom with more than $1,30,000$ recently known species, they are next to the arthropods. Most reports on the chromosomes of molluses using histological or squash techniques have dealt chiefly, with chromosome numbers (Patterson, 1969; Patterson and Burch, 1978). The molluscs greatly vary in form, structure, habit and habitats. They are highly adaptive and occupy all possible aquatic and terrestrial habitats. The phylum includes animals of wide diversity in form, such as the common slugs and snails, slow moving chitons, oysters and clams, swift darting squids, slithering octopuses and the chambered nautilus. Cytogenetic studies contribute useful information supplementary to the morphological, biochemical and other characters used for systematic analysis of freshwater snails. Approximately 60,000 species of Gastropods are known, out of which only 332 species have been worked out cytogenetically till date (305 were karyotyped and 27 included banding techniques), showing 
the increasing knowledge of chromosome morphology over the last three decades.

Family Planorbidae are small, air breathing freshwater aquatic pulmonate gastropod snail which lives on water plants. They usually prefer small ponds and serves as an important intermediate host for several trematodes parasites. These are hermaphroditic, invasive snails with high fecundity. It is responsible for the transmission of Schistosoma, which infect cattle and cause reduced livestock productivity. They act as scavengers providing a useful function of breaking down decaying plants and animals and also eat algae. Its shell is greyish, umbilicus broad and shallow. Aperture strongly oblique, shell nearly smooth, sculptured with irregularly spaced striations. These are air breathing freshwater snail. Shell discoidal, upper and lower side concave, with regular fine axial riblets, aperture large, sharp peristome without lip.

\section{Materials and Methods}

The snails were collected from Nud pond, Jammu from slow running fresh water streams. Snails were taken alive to the laboratory, then maintained in tanks of aerated water and fed continuously to promote growth. Chromosome preparations were obtained from the ovotestis. After taxonomic verification of each snail, pooled snails (about 10 snails for each species Injection was given intramuscularly of $0.1 \%$ colchicine at the rate of $1 \mathrm{ml} / 100 \mathrm{mg}$ body weight for $24 \mathrm{hrs}$. Snails were dissected and their ovotestis removed and treated with $0.07 \% \mathrm{KCl}$ as hypotonic solution, at room temperature for $30 \mathrm{~min}$. The tissues after hypotonic treatment were fixed in Carnoy's fixative. The slides were stained with $4 \%$ Giemsa buffer solution for $30 \mathrm{~min}$. scanning and photomicrography of the slides was done using Nikon YS100 binocular research microscope and Samsung SDC-313 camera respectively. Well spread suitable mitotic stages were photomicrographed at a magnification of $1000 \mathrm{x}$. The morphological classification of chromosomes proposed by (Levan et al., 1964) has been followed to categorize the chromosomes as metacentrics, submetacentrics, subtelocentrics or telocentric. The chromosomes were classified into uniarmed and biarmed following (Chen and Ebelling, 1971) to calculate the fundamental arm number (FN). Idiogram and Histogram was prepared.

\section{Observations}

Gyraulus ladacensis (Fig.1) - Spermatogonial metaphase plates were selected for preparing. A total of 40-50 metaphase stages were selected to establish the diploid chromosome number. The basic chromosome number was found to be $2 n=36$ (Fig.3). All chromosomes in both the karyotypes were biarmed and of three types, that is, metacentric, submetacentric and subtelocentric type. Haploid formula for the complement was calculated as $n=14 \mathrm{M}+3 \mathrm{SM}+1 \mathrm{ST}$ and the corresponding fundamental arm number was calculated as $\mathrm{NF}=72$ (Fig.4). Mean haploid length was $15.95 \mu \mathrm{m}$ and Total diploid length $=31.90 \mu \mathrm{m}$. Morphometric data of the karyotype is given in the Table 1. Histogram (Fig.5) and idiogram (Fig.6) were prepared using morphometric data.

Meiotic stages observed included leptotene characterized by the presence of a ball of coiled chromatin material. Second stage was zygotene in which all the chromosomes were attached to one end to form a characteristic bouquet like structure. Third stage was pachytene in which the chromosome threads were more condensed and associated. In Diplotene, the characteristics bivalent shape was observed. Bivalents were long and slender. Metaphase I was characterized by the presence of eighteen bivalents exhibiting different configurations according to the 
number and position of chiasmata. The mature male spermatozoon was very long, uniflagellate composed of a conical head (Fig 7a-f).

Indoplanorbis exustus (Fig.2) - A total of 4050 metaphase stages were selected to establish the diploid chromosome number. The basic chromosome number was found to be $2 n=36$ (Fig.8). All chromosomes in both the karyotypes were biarmed and metacentric type. Haploid formula for the complement was calculated as $n=18 \mathrm{M}$ and the corresponding fundamental arm number was calculated as $\mathrm{NF}=72$ (Fig.9). Mean haploid length was $16.23 \mu \mathrm{m}$ and total diploid length $=32.46 \mu \mathrm{m}$. Morphometric data of the karyotype is given in the Table 2. Histogram (Fig.10) and ideogram (Fig.11) were prepared using
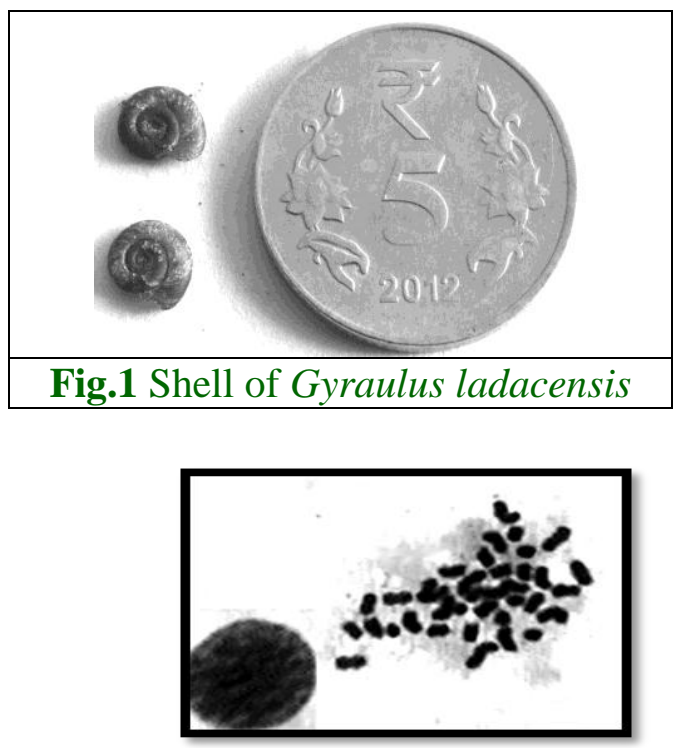

Fig. 3 Spermatogonial metaphase complement

G.ladacensis showing $2 \mathrm{n}=36$

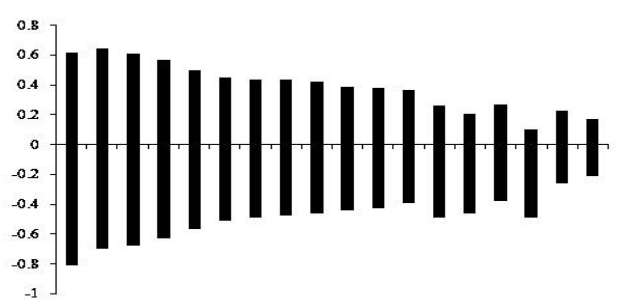

Fig.5 Histogram of G. ladacensis morphometric data. Various meiotic stages were observed in ovotestis cells and they are: Leptotene Stage, in which the chromosomes were forming chromatin network by crossing and intercrossing. Zygotene stage which is characterized by presence of double twisted and interlaced chromosomal threads.

In Pachytene stage, chromosomes were present in paired form as tetrads much thicker than the leptotene hreads. However, their number was not countable. In Diplotene, bivalents were long and slender and in Diakinesis, eighteen bivalents were observed in the form of rings mostly exhibiting terminal chiasmata each ring having two chiasmata per bivalent. The mature male spermatozoon was very long, uniflagellate composed of a conical head (Fig.12 a-f).
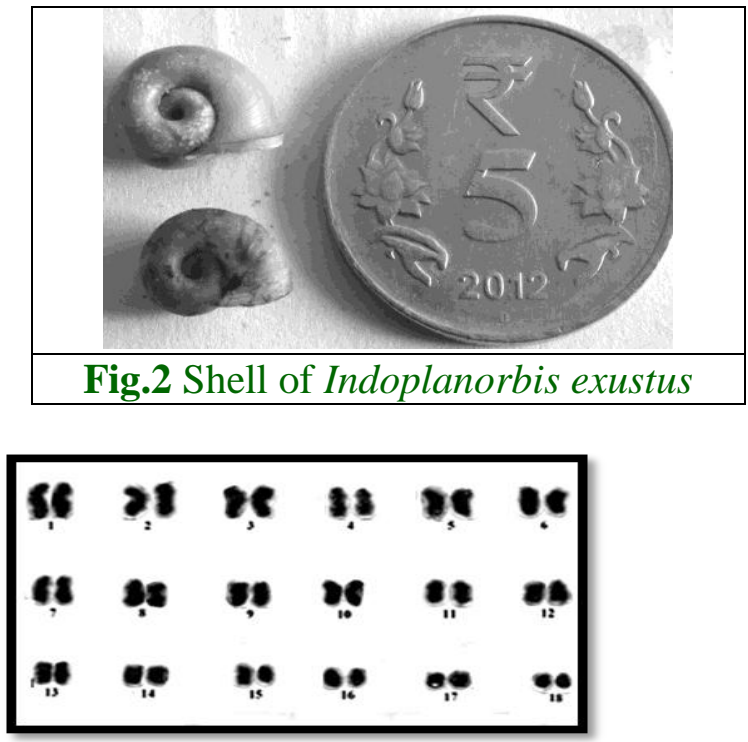

Fig. 4 Karyotype of spermatogonial metaphase complement

$(28 m+6 s m+2 s t)$ of G. ladacensis

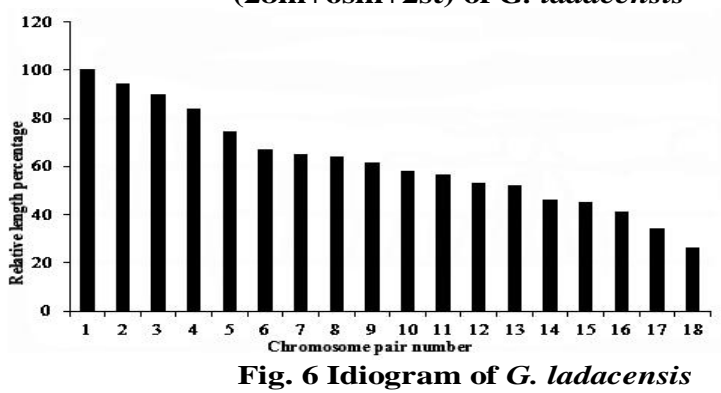


Fig.7 G. ladacensis : Different stages of meiosis a. leptotene stage b. Zygotene Stage c.

Pachytene stage d. Diplotene stage e. Diakinesis stage
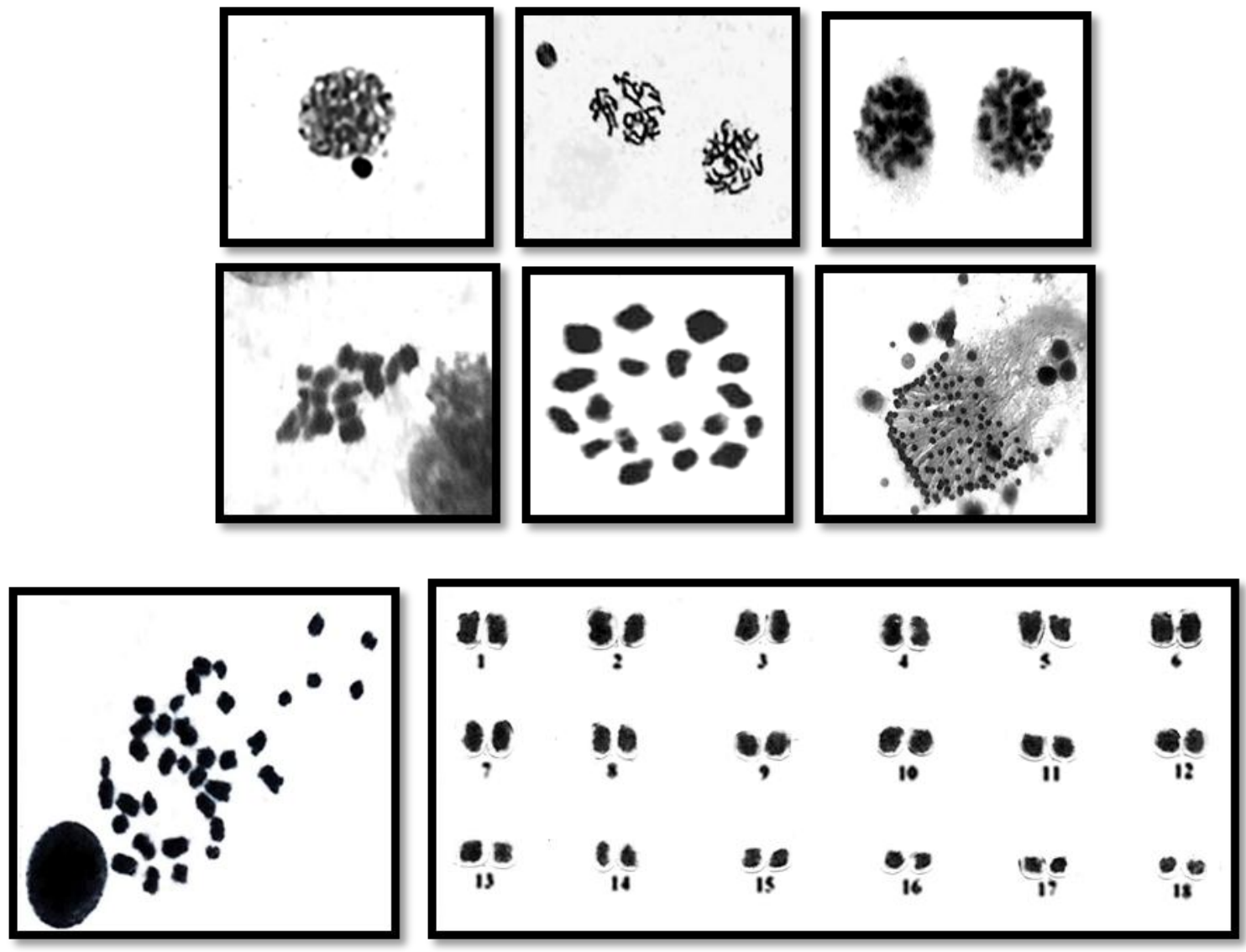

Fig. 8 Spermatogonial metaphase complement of

Fig. 9 Karyotype of spermatogonial metaphase

Indoplanorbis exustus (2n=36)

complement of $I$ exustus ( $2 \mathrm{n}=36,18$ metacentric chromosomes).

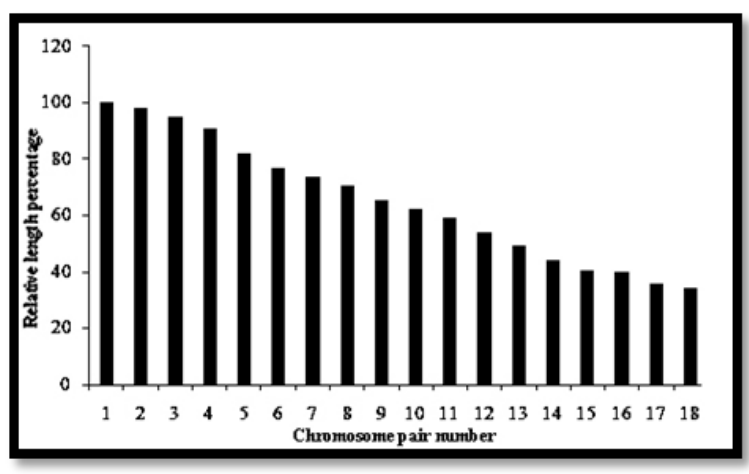

Fig.10 Histogram of I. exustus

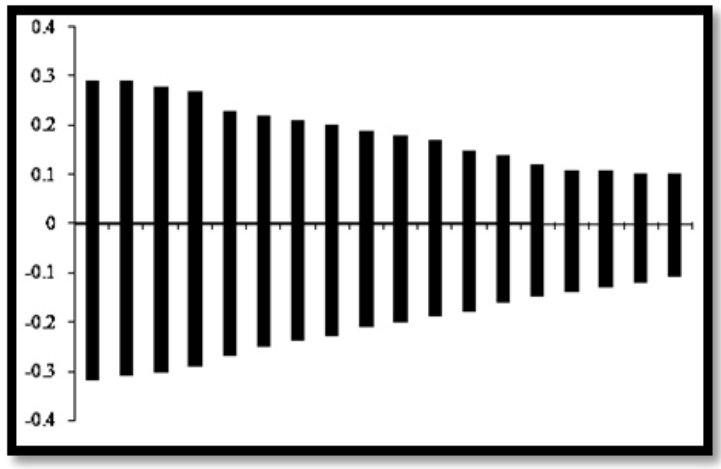

Fig. 11 Idiogram of I. exustus 
Fig.12 I. exustus: Different stages of meiosis a. leptotene stage b. Zygotene Stage c. Pachytene stage d. Diplotene stage e. Diakinesis stage
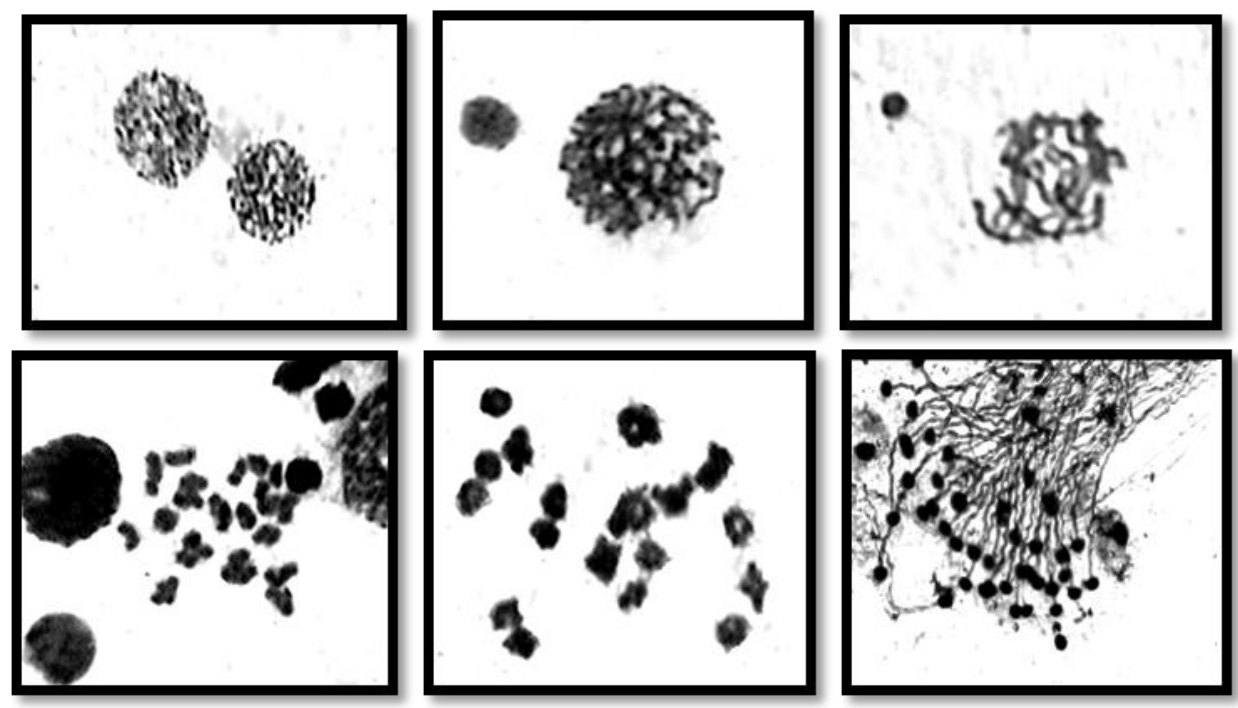

Table.1 Morphometric data of karyotype of $G$. ladacensis showing $2 n=36(28 m+6 s m+2 s t)$

\begin{tabular}{|c|c|c|c|c|c|c|c|c|}
\hline $\begin{array}{c}\text { Chromoso } \\
\text { me pair } \\
\text { no. }\end{array}$ & $\begin{array}{l}\text { Mean } \\
\text { length of } \\
\text { the short } \\
\text { arm (p) } \\
\text { in um }\end{array}$ & $\begin{array}{c}\text { Mean } \\
\text { length of } \\
\text { the } \\
\text { long arm } \\
\text { (q) in } \mu \mathrm{m}\end{array}$ & $\begin{array}{c}\text { Absolute } \\
\text { length }(p+q) \\
\text { of the } \\
\text { chromosome } \\
\text { in } \mu \mathrm{m}\end{array}$ & $\begin{array}{l}\text { Arm } \\
\text { ratio } \\
(\mathbf{q} / \mathbf{p})\end{array}$ & $\begin{array}{c}\text { Relative } \\
\text { length } \\
\text { percentage }\end{array}$ & $\begin{array}{c}\text { Total } \\
\text { complement } \\
\text { length } \\
\text { percentage }\end{array}$ & $\begin{array}{l}\text { Centromeric } \\
\text { index }\end{array}$ & Nomenclature \\
\hline 1 & 0.62 & 0.81 & 1.43 & 1.30 & 100.00 & 4.48 & 43.35 & Metacentric \\
\hline 2 & 0.65 & 0.70 & 1.35 & 1.07 & 94.40 & 4.23 & 48.14 & Metacentric \\
\hline 3 & 0.61 & 0.68 & 1.29 & 1.11 & 90.20 & 4.04 & 47.28 & Metacentric \\
\hline 4 & 0.57 & 0.63 & 1.20 & 1.10 & 83.91 & 3.76 & 47.50 & Metacentric \\
\hline 5 & 0.50 & 0.57 & 1.07 & 1.26 & 74.82 & 3.35 & 46.72 & Metacentric \\
\hline 6 & 0.45 & 0.51 & 0.96 & 1.13 & 67.13 & 3.00 & 46.87 & Metacentric \\
\hline 7 & 0.44 & 0.49 & 0.93 & 1.11 & 65.03 & 2.91 & 47.31 & Metacentric \\
\hline$\overline{8}$ & 0.44 & 0.48 & 0.92 & 1.09 & 64.33 & 2.88 & 47.82 & Metacentric \\
\hline 9 & 0.42 & 0.46 & 0.88 & 1.09 & 61.53 & 2.75 & 47.72 & Submetacentric \\
\hline 10 & 0.39 & 0.44 & 0.83 & 1.12 & 58.04 & 2.60 & 46.98 & Metacentric \\
\hline 11 & 0.38 & 0.43 & 0.81 & 1.13 & 56.64 & 2.53 & 46.91 & Metacentric \\
\hline 12 & 0.37 & 0.39 & 0.76 & 1.05 & 53.14 & 2.38 & 48.68 & Metacentric \\
\hline 13 & 0.26 & 0.49 & 0.75 & 1.88 & 52.44 & 2.35 & 34.66 & Submetacentric \\
\hline 14 & 0.20 & 0.46 & 0.66 & 2.30 & 46.15 & 2.06 & 30.30 & Submetacentric \\
\hline 15 & 0.27 & 0.38 & 0.65 & 1.40 & 45.45 & 2.03 & 41.53 & Metacentric \\
\hline 16 & 0.10 & 0.49 & 0.59 & 4.90 & 41.25 & 1.84 & 16.94 & Subtelocentric \\
\hline 17 & 0.23 & 0.26 & 0.49 & 1.13 & 34.26 & 1.53 & 46.93 & Metacentric \\
\hline 18 & 0.17 & 0.21 & 0.38 & 1.23 & 26.57 & 1.19 & 44.73 & Metacentric \\
\hline
\end{tabular}


Table.2 Morphometric data of karyotype of I. exustus showing 2n=36 (all metacentric)

\begin{tabular}{|c|c|c|c|c|c|c|c|c|}
\hline $\begin{array}{c}\text { Chromos } \\
\text { ome pair } \\
\text { no. }\end{array}$ & $\begin{array}{c}\text { Mean } \\
\text { length of } \\
\text { the short } \\
\text { arm (p) in } \\
\text { um }\end{array}$ & $\begin{array}{c}\text { Mean } \\
\text { length of } \\
\text { the long } \\
\text { arm (q) in } \\
\text { um }\end{array}$ & $\begin{array}{c}\text { Absolute } \\
\text { length }(p+q) \\
\text { of the } \\
\text { chromosome } \\
\text { in } \mu \mathrm{m}\end{array}$ & $\begin{array}{l}\text { Arm } \\
\text { ratio } \\
(q / p)\end{array}$ & $\begin{array}{c}\text { Relative } \\
\text { length } \\
\text { percentage }\end{array}$ & \begin{tabular}{|c|} 
Total \\
complement \\
length \\
percentage
\end{tabular} & $\begin{array}{c}\text { Centromeric } \\
\text { index }\end{array}$ & Nomenclature \\
\hline 1 & 0.29 & 0.32 & 0.61 & 1.10 & 100.00 & 4.25 & 47.54 & Metacentric \\
\hline 2 & 0.29 & 0.31 & 0.60 & 1.06 & 98.36 & 4.18 & 48.33 & Metacentric \\
\hline 3 & 0.28 & 0.30 & 0.58 & 1.07 & 95.08 & 4.05 & 48.27 & Metacentric \\
\hline 4 & 0.27 & 0.29 & 0.56 & 1.07 & 91.08 & 3.91 & 48.21 & Metacentric \\
\hline 5 & 0.23 & 0.27 & 0.50 & 1.17 & 81.96 & 3.49 & 46.00 & Metacentric \\
\hline 6 & 0.22 & 0.25 & 0.47 & 1.13 & 77.04 & 3.28 & 46.80 & Metacentric \\
\hline 7 & 0.21 & 0.24 & 0.45 & 1.14 & 73.77 & 3.14 & 46.66 & Metacentric \\
\hline 8 & 0.20 & 0.23 & 0.43 & 1.09 & 70.49 & 3.00 & 46.51 & Metacentric \\
\hline 9 & 0.19 & 0.21 & 0.40 & 1.10 & 65.57 & 2.79 & 47.50 & Metacentric \\
\hline 10 & 0.18 & 0.20 & 0.38 & 1.11 & 62.29 & 2.65 & 47.36 & Metacentric \\
\hline 11 & 0.17 & 0.19 & 0.36 & 1.11 & 59.01 & 2.51 & 47.22 & Metacentric \\
\hline 12 & 0.15 & 0.18 & 0.33 & 1.20 & 54.09 & 2.30 & 45.45 & Metacentric \\
\hline 13 & 0.14 & 0.16 & 0.30 & 1.14 & 49.18 & 2.09 & 46.66 & Metacentric \\
\hline 14 & 0.12 & 0.15 & 0.27 & 1.25 & 44.26 & 1.88 & 44.44 & Metacentric \\
\hline 15 & 0.11 & 0.14 & 0.25 & 1.27 & 40.26 & 1.74 & 44.00 & Metacentric \\
\hline 16 & 0.11 & 0.13 & 0.24 & 1.18 & 39.34 & 1.67 & 45.83 & Metacentric \\
\hline 17 & 0.10 & 0.12 & 0.22 & 1.09 & 36.06 & 1.53 & 45.45 & Metacentric \\
\hline 18 & 0.10 & 0.11 & 0.21 & 1.10 & 34.42 & 1.46 & 47.61 & Metacentric \\
\hline
\end{tabular}

In family Planorbidae, twenty species were studied cytologically so far. Some workers only studied the diploid chromosome number of seven species of family Planorbidae viz. Ceratophallus natalensis, 36 (Brown, 2001); Helisoma subcrenatum, 36 (Bonham, 1955); Gyraulus deflectus, H. anceps, H. trivolvis, Promenetus exacuous, 36 (Burch, 1960) and Planorbis cornuta, 36 (Le-Calvez and Certain, 1950). In Biomphalaria glabarata (Azevedo and Gonzalves, 1956; Goldman et al., 1983b; Goldman et al., 1984; Kawano et al., 1987); B. straminea (Goldman et al., 1983b; Goldman et al., 1984; Kawano et al., 1987) and B. tenagophila (Kawano et al., 1987), diploid chromosome number of $2 n=36$ was recorded with $30 \mathrm{~m}+4 \mathrm{sm}+2 \mathrm{st}$ chromosomes $\quad(\mathrm{FN}=72), \quad 32 \mathrm{~m}+2 \mathrm{sm}+2 \mathrm{st}$ chromosomes $(\mathrm{FN}=72)$ and $24 \mathrm{~m}+8 \mathrm{sm}+4 \mathrm{st}$ chromosomes $(\mathrm{FN}=72)$ respectively. In four species of genus Planorbarius viz. $P$. corneus, $P$. banaticus, $P$. purpura, $P$. grandis (Garbar and Garbar, 2007) and two species of genus Bulinus viz. B. natalensis and $B$. tropicus (Goldman et al., 1980; Kawano et al., 1985) a diploid count of 36 chromosomes comprising $30 \mathrm{~m}+6 \mathrm{sm}$ chromosomes $(\mathrm{FN}=72)$ was reported. Diploid chromosome number of $2 \mathrm{n}=36$ in Helisoma duryi and Hippeutis cantori with $26 \mathrm{~m}+10 \mathrm{sm}$ chromosomes $(\mathrm{FN}=72)$ and $28 \mathrm{~m}+8 \mathrm{sm}(\mathrm{FN}=72)$ respectively (Park, 1994; Choudhary and Pandit, 1993).

The diploid chromosome number in geographically isolated populations of Indoplanorbis exustus viz. Orissa population (18) and Jammu population (present study) was $2 n=36$ with all metacentric chromosomes 
$(\mathrm{FN}=72)$. There was no difference in diploid number, chromosome morphology and fundamental arm number of two populations, this suggested karyotypic conservation. Gyraulus ladacensis worked out for the first time in present study (Jammu) has diploid complement of $2 n=36$, with $28 m+6 s m+2 s t$ chromosomes $(\mathrm{FN}=72)$. Diploid chromosome number of $2 \mathrm{n}=36$ with fundamental arm number of 72 suggested the presence of only biarmed chromosomes in the family Planorbidae. These two species has been studied for the very first time and they will Robertsonian mechanisms and pericentric inversions have been found to play a key role in the karyotypic evolution of molluscs.

\section{References}

Azevedo, J.F.D. and Gonzalves, M.M. Ensaios sobre o estudo da numeracao cromosmica de algumas especies de Moluscos de aqua doce. Anais Inst. Med. Trop., 1956; 13(4): 569-577.

Bonham, K. Sensitivity to X-rays of the early cleavage stages of the snail Helisoma subcrenatum. Growth, 1955; 19(1): 918.

Brown, D.S. Taxonomy, biogeography and phylogeny of the non-lacustrine African freshwater snails belonging to the genera Ceratophallus and Afrogyrus (Mollusca: Planorbidae). Journal of Zoology, 2001; 255: 55-82.

Burch, J.B. Chromosome morphology of aquatic pulmonate snails. Trans. Of Ame. Micro Society, 1960; 79(4): 451461.

Chen, T.R. and Ebelling, A.W. Chromosomes of the goby fishes in the genus Gallichthys. Copeia, 1971; 1: 171-174.

Choudhary, R. and Pandit, R.K. Mitotic and meiotic chromosomes of a freshwater snail, Indoplanorbis exustus (Basommatophora: Planorbidae).
Journal of Medical and Applied Malacology, 1993; 5: 139-140.

Garbar, D.A. and Garbar, A.V. Karyological features of the genus Planorbarius (Gastropoda: Pulmonata: Bulinidae) of the Ukrainian Fauna. Cytology and Genetics, 2007; 41(2): 109-114.

Goldman, M.A., Loverde, P.T. and Chrisman, C.L. Comparative karyology of the freshwater snails Bulinus tropicus and B. natalensis. Canadian Journal of Genetics and Cytology, 1980; 22: 361367.

Goldman, M.A., Loverde, P.T., Chrisman, C.L. and Franklin, D.E. Chromosomal evolution in planorbid snails of the genera Bulinus and Biomphalaria. Malacologia, 1984; 25: 427-446.

Goldman, M.A., Loverde, P.T., Chrisman, C.L., Franklin, D.A., Matthews, F., Pitchford, R.J. and Richard, C.S. Nucleolar organizer regions in Biomphalaria and Bulinus snails. Experientia, 1983b; 39: 911-913.

Kawano, T., Simoes, L.C.G. and Toledo, L.F.A. Karyotype and nucleolar organizer regions of Helisoma duryi (Wetherby, 1897). Rev. Brasil. Genetics, 1985; 2: 285-290.

Kawano, T., Simoes, L.C.G. and Toledo, L.F.A. Nucleolar organizer region in three species of the genus Biomphalaria (Mollusca: Gastropoda). Rev. Brasil. Genetics, 1987; 4: 695-707.

Le-Calvez, J. and Certain, P. Donndes caryologiques sur quelques Pulmonds basommatophores. C. R. Acad. Sci., Paris, 1950; 231(16): 794-795.

Levan, A., Fredga, K. and Sandberg, A.A. Nomenclature for Centromeric position on chromosomes. Hereditas, 1964; 52: 201-220.

Park, G.M. Cytotaxonomic studies of freshwater gastropods in Korea. Malacological Review, 1994; 27: 2341. 
Patterson, C.M. and Burch, J.B. Patterson, C.M. Chromosomes of molluscs. Chromosomes of pulmonate molluscs. In: Proceedings of the $2^{\text {nd }}$ Symposium In: Pulmonates: systematics, evolution of Mollusca, Ernakulam, Cochin, India. and ecology, 2A. (V. Fretter \& J. Peake, Marine Biological Association of India, eds). Academic Press, New York, 1978; $\quad$ 1969; 2: 635-689. pp. 171-217.

\section{How to cite this article:}

Poonam, N.K. Tripathi and Preetpal Kour. 2018. Karyotypic and Morphometric Studies in Two Species of Family Planorbidae (Gastropoda: Mollusca). Int.J.Curr.Microbiol.App.Sci. 7(09): 1180-1187. doi: https://doi.org/10.20546/ijcmas.2018.709.140 